\title{
Investigating Radical Deaths and the Cultures That Practiced Them: New AHRC Funded Research at the Institute of Archaeology
}

\author{
Brenna R. Hassett*, David Wengrow* and Haluk Sağlamtimur ${ }^{\dagger}$
}

A new Arts and Humanities Research Council (AHRC) funded project brings together multiple strands of investigation to probe the relationship between ritual, violence, and early state formation. David Wengrow and Brenna Hassett will coordinate an international team combining biomolecular analysis (stable isotopes, ancient DNA), bioarchaeology, and archaeology to examine a remarkable set of Early Bronze Age funerary deposits (c. 3100-2800 BC), excavated at the multi-period site of Başur Höyük, in South-eastern Turkey. They include evidence of extraordinary wealth combined with radically new cultural practices, such as mass death pits and burials of retainers or other human victims. Such findings add to a growing body of archaeological data from the Middle East, which is now prompting researchers to rethink key aspects of social and political change at the start of the Bronze Age.

In the summer of 2014, a remarkable discovery was made in South-eastern Turkey. In advance of the construction of the Ilisu Dam, a team led by Dr Haluk Sağlamtimur of Ege University had been conducting rescue excavations along the proposed flood path for over a decade. This team identified a number of archaeological sites, among them the mound site of Başur Höyük, situated near the modern town of Siirt on the Basur River, an offshoot of the network of watercourses feeding the upper reaches of the Tigris River. Intensive excavation at Başur revealed some 7,000 years of occupation, stretching from

\footnotetext{
* UCL Institute of Archaeology, London WC1H OPY, $\mathrm{GB}$

† Ege University, Faculty of Letters, Department of Archaeology, Bornova-iZMiR, TR

Corresponding author: Brenna R. Hassett (b.hassett@ucl.ac.uk)
}

the Ubaid period to the very recent past (Sağlamtimur 2017). Of particular interest was the presence of Southern Mesopotamian material culture from the later centuries of the $4^{\text {th }}$ millennium BC. This in itself was not surprising. It has been known for some decades that the growth of urban societies in southern Iraq and western Iran, from around 3500 BC, was accompanied by the spread of commercial and religious outposts far up the Euphrates and Tigris Rivers, towards the foothills of the Taurus and Zagros Mountains. More unusual, and surprising, was the recovery from Başur of direct information about what happened after this extended network of outposts and colonies collapsed, around 3100 BC, at the start of the Bronze Age.

In the wider Middle East, the transition between the $4^{\text {th }}$ and $3^{\text {rd }}$ millennium BC has long been recognised as a crucial period for understanding the emergence of warrior 
elites, political and administrative centralisation, and wider transformations in urban life, including the emergence of kingship. How these various processes related to one another in time and space remains a topic of intense debate. For this reason, the identification of an immensely wealthy cemetery dating to the Early Bronze Age 1 period (c. 3100-2800 BC) at Başur Höyük-a small site of less than four hectares (Figure 1)-is of considerable interest, providing a local window onto broader regional developments. Its discovery complements recent findings at Arslantepe, in the Malatya Plain, which suggest the initial development of warrior-aristocraciessignified by the appearance of elaborate weaponry, spectacular burials in constructed tombs, and a possible palace-on the highland margins of Mesopotamia, and not in the more populous urban centres of the lowland steppe and floodplain (Frangipane 1997, 2006). Especially striking, both at Arslantepe and Başur, is unprecedented evidence for the killing of human victims, as part of elite burial rites (Frangipane 2006; Hassett and Sağlamtimur 2018): a practice that recurs, some centuries later, in the 'Royal Tombs of Ur,' far to the south (Woolley 1954; but see also Baadsgaard 1997; Baadsgaard et al. 2011). The cemetery complex discovered at Başur Höyük offers a unique opportunity to examine the development of the Anatolian societies directly implicated in these wider transformations.

At Başur Höyük, both stone cist graves and pit graves date to the period in question. Some contain more than one individual and striking grave goods, including copper-alloy spear and axe heads (Hassett and Sağlamtimur in press; Sağlamtimur and Massimino 2015), as well as what may be the earliest clear examples of gaming pieces from this region (Sağlamtimur 2017; Sağlamtimur and Ozan 2014). Evidence of violence was also found, in the form of eight young individuals some exhibiting skull fractures and stab wounds - laid to rest at the feet of two child burials (Hassett and Sağlamtimur 2018).

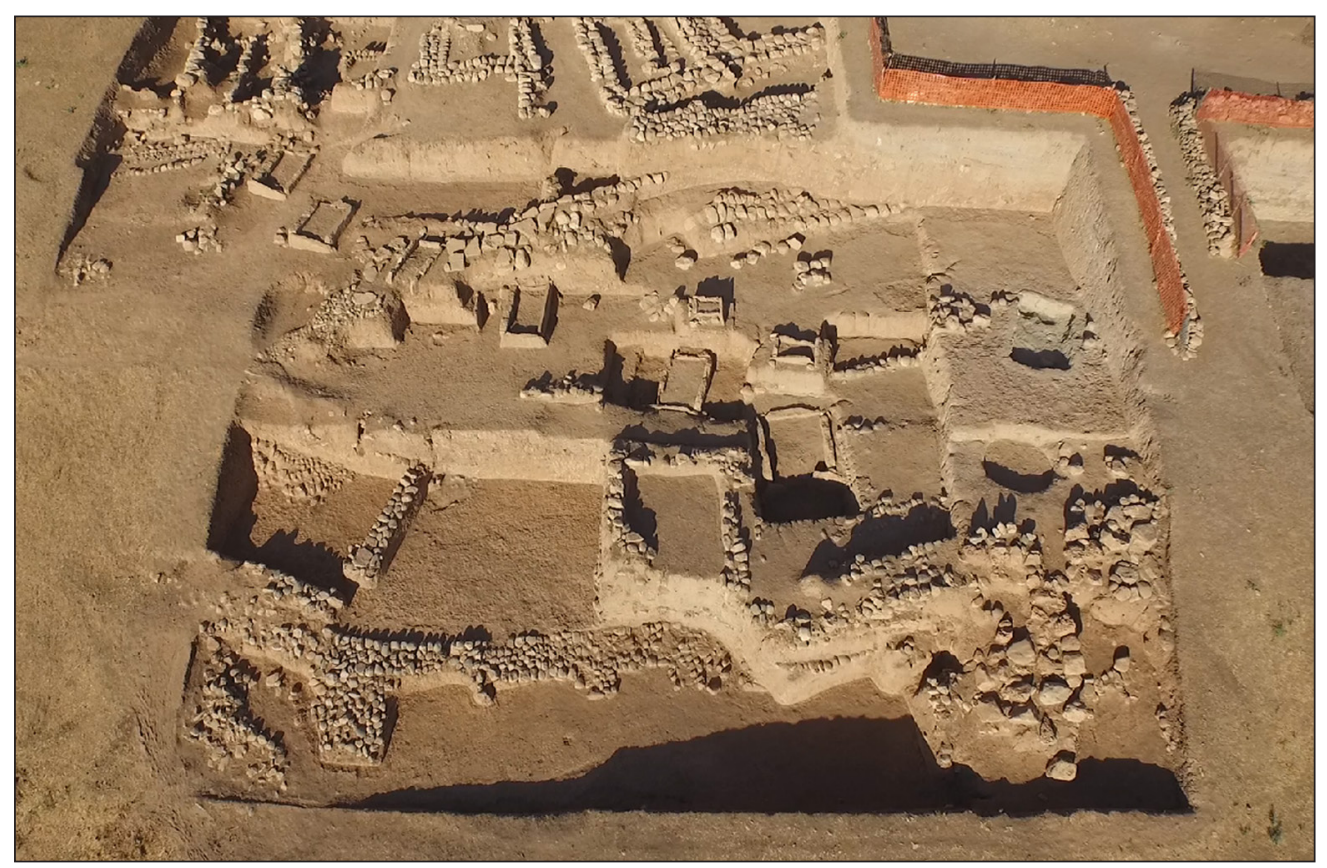

Figure 1: Overview of the EBA 1 Cemetery showing cist graves with retainer burial and pit graves with mass burial. North is to the right of the image. Figure: Başur Höyük Research Project. 
A further season of excavation in 2014 brought important new discoveries. To the north of, and contemporaneous with, the Early Bronze Age 1 cemetery, archaeologists found a small pit, measuring approximately $3.30 \times 2.00$ metres. Upon removal of the upper fill, it quickly became apparent that this was a mass burial containing the skeletal remains of approximately 60 individuals piled on top of each other, and crammed tightly into a confined space (Figure 2). The discovery of this pit-in combination with existing evidence of cist tombs and retainer burialadds a further, intriguing dimension to the study of Başur Höyük's funerary landscape.

In 2015, a dedicated physical anthropology team led by Brenna Hassett systematically excavated the mass-burial pit, using a combination of single context, gridded, and photogrammetric recording techniques to capture as much information as possible during the limited field season. In 2018, the Arts and Humanities Research Council UK awarded Hassett and David Wengrow funding for a new project to consider the wider implications of these findings. The project, a collaboration between the UCL Institute of Archaeology and several partner institutions, will work at a variety of scales, ranging from the molecular structure of the bones all the way up to global and comparative debates concerning the role of ritual violence in processes of early state formation (see, for e.g., Campbell 2014). International Co-Investigator Suzanne Pillar Birch will be investigating ratios of stable isotopes in the bones and teeth to give information about diet, origin, and mobility in the graves and pits of Başur Höyük's cemetery at the Center for Applied Isotope Studies in the University of Georgia, Athens. Ian Barnes and Selina Brace of the Natural History Museum will analyse aDNA extracted from human remains, with the aim of shedding light on biological relationships among the various classes of burials in the Early Bronze Age cemetery. At UCL, the emphasis will be on integrating the results of molecular analyses with wider patterns of biological and archaeological evidence, gained through collaboration with Haluk

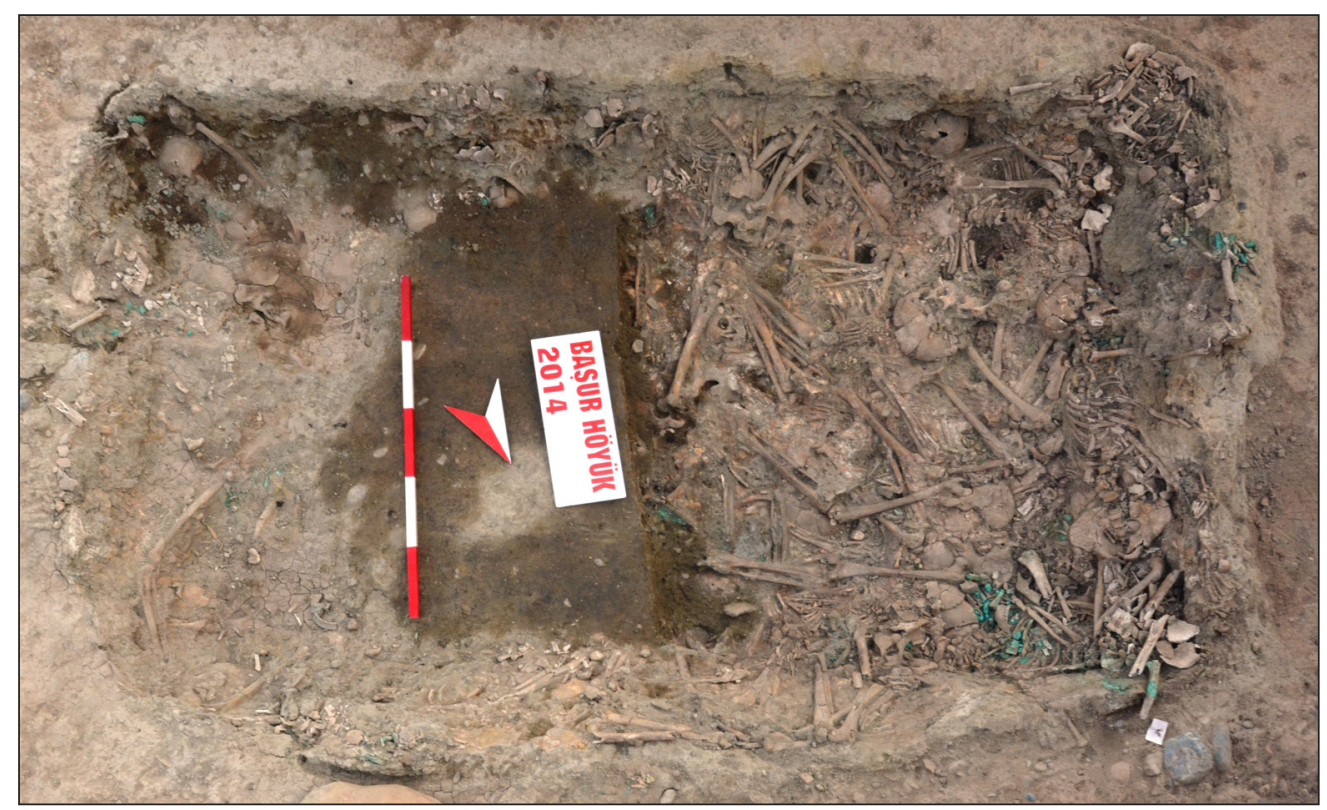

Figure 2: The mass death pit, which is central to new investigations of the use and function of radical death practices in the formation of early states as part of the Radical Death Project. Ranging pole is $2.5 \mathrm{~m}$, arrow is to North. Figure: Başur Höyük Research Project. 
Sağlamtimur and his team at Ege University. This will provide a basis for considering the following questions:

- What can we learn about the composition of those groups buried at Başur Höyük - in terms of mobility, health, and degrees of relatedness - and how they differed or marked themselves out from other elements of the local population?

- What light does this evidence shed on wider social transformations, including new forms of elite identity, associated with the emergence of courtly societies and warrior-aristocracy in Southwest Asia, at the start of the Bronze Age?

- How can such archaeological investigations at the micro-scale inform broader anthropological debates, concerning the roles of violence and ritual in processes of early state formation?

\section{Ethics and Consent}

This research meets all available ethics guidelines.

\section{Funding Information}

Initial support for the physical anthropological investigation at Başur Höyük was provided by the BIAA Study Grant Scheme. Ongoing funding is provided by the Arts and Humanities Research Council UK Research Grant, and small grants from the BIAA.

\section{Competing Interests}

The authors have no competing interests to declare.

\section{Author Contributions}

The main text was composed and revised by $\mathrm{BH}$ and DW based on extensive discussion with BH, DW, and HS. Archaeological context comes from HS and DW, while bioarchaeological information comes from $\mathrm{BH}$.

\section{References}

Baadsgaard, A 1997 Bludgeoned, Burned, and Beautifed: Reevaluating Mortuary Practicesin the Royal Cemetery of Ur.
In: Porter, A M and Schwartz, G M (eds.) Sacred Killing: The Archaeology of Sacrifce in the Ancient Near East. Winona Lake: Eisenbrauns. pp. 125-158.

Baadsgaard, A, Monge, J, Cox, S and Zettler, R L 2011 Human sacrifice and intentional corpse preservation in the Royal Cemetery of Ur. Antiquity, 85: 27-42. DOI: https://doi.org/10.1017/ S0003598X00067417

Campbell, R (ed.) 2014. Violence and Civilization: Studies of Social Violence in History and Prehistory. Oxford: Oxbow Books. DOI: https://doi.org/10.2307/j. ctvh1dscc

Frangipane, M 1997 A 4th-millennium temple/palace complex at ArslantepeMalatya. North-South relations and the formation of early state societies in the Northern regions of Greater Mesopotamia. Paléorient, 23: 45-73. DOI: https:// doi.org/10.3406/paleo.1997.4644

Frangipane, M 2006 The Arslantepe 'Royal Tomb': new funerary customs and political changes in the Upper Euphrates valley at the beginning of the third millennium BC. In: Bartoloni, $G$ and Benedettini, $M$ G (eds.) Buried Among the Living. Rome: Università degli studi di Roma "La Sapienza». pp. 169-194.

Hassett, B R and Sağlamtimur, H 2018 Radical 'Royals'? New evidence from Başur Höyük for radical burial practices in the transition to early states in Mesopotamia. Antiquity, 92: 640-654. DOI: https://doi.org/10.15184/aqy.2018. 63

Hassett, B R and Sağlamtimur, H In press The radical death of the 4 th millennium: contextualising human sacrifice at Başur Höyük. In: Laneri, N (ed.) Sanem Series.

Sağlamtimur, H 2017 Siirt-Başur Höyük Erken Tunç Çağı I Mezarları: Ön rapor. In: Aytaçlar, M N, Abay, E, Dedoğlu, F and Erdoğan, A (eds.) Arkeoloji Derigisi. İzmir: Ege Üniversitesi. pp. 1-18.

Sağlamtimur, $\mathbf{H}$ and Massimino, M G M 2015 Wealth sacrifice and legitimacy: the case of the Early Bronze Age Başur Höyük 
cemetery (south-eastern Turkey). In: Horejs, B, Schwall, C, Müller, V, Luciani, M, Ritter, M, Giudetti, M, Salisbury, R B, Höflmayer, F and Bürge, T (eds.) Proceedings of the 10th International Congress on the Archaeology of the Ancient Near East. 25-29 April 2016, Vienna. Volume 1. Wiesbaden: Harrassowitz
Verlag. pp. 329-342. DOI: https://doi. org/10.2307/j.ctvcm4f86.30

Sağlamtimur, H and Ozan, A 2014 SiirtBaşur Höyük 2012 Yılı Çalışmaları. Kazı Sonuçları Toplantısı 3, 2014 Cilt, Muğla Kazı Sonuçları Toplantısı 3.

Woolley, L C 1954 Excavations at Ur. London: Ernest Benn Limited.

How to cite this article: Hassett, B R, Wengrow, D and Sağlamtimur, H 2019 Investigating Radical Deaths and the Cultures That Practiced Them: New AHRC Funded Research at the Institute of Archaeology. Archaeology International, 22(1), pp. 61-65. DOl: https://doi.org/10.5334/ai-398

Copyright: (c) 2019 The Author(s). This is an open-access article distributed under the terms of the Creative Commons Attribution 4.0 International License (CC-BY 4.0), which permits unrestricted use, distribution, and reproduction in any medium, provided the original author and source are credited. See http://creativecommons.org/licenses/by/4.0/. 